\title{
Morphological and Yield Response of Pulses Against Drought Stress: A Review
}

\author{
Aqsa Tahir ${ }^{*}$, Masood Qadir², Rabia Saif ${ }^{3}$, Saira Sattar $^{4}$, Sidra Tahir $^{5}$ \\ ${ }^{1 *}$ Department of Plant Breeding and Genetics, University of Agriculture Faisalabad, Pakistan \\ Corresponding author, E-mail: aqsatahir24@yahoo.com, ORCID: https://orcid.org/0000-0002-7906-0924 \\ ${ }^{2}$ Department of Plant Breeding and Genetics, University of Agriculture Faisalabad, Pakistan \\ E-mail: masoodpbg@yahoo.com,ORCID: https://orcid.org/0000-0002-9821-8782 \\ ${ }^{3}$ Department of Plant Breeding and Genetics, University of Agriculture Faisalabad, Pakistan \\ E-mail:rabiasaif03@gmail.com,ORCID: https://orcid.org/0000-0002-0437-8241 \\ ${ }^{4}$ Department of Plant Breeding and Genetics, University of Agriculture Faisalabad, Pakistan \\ E-mail: sairasattar9@yahoo.com \\ ${ }^{5}$ Institute of Soil and Environmental Sciences, University of Agriculture Faisalabad, Pakistan. \\ E-mail: sidrachaudhary290@yahoo.com,ORCID: https://orcid.org/0000-0002-8581-4438
}

\begin{tabular}{|c|c|}
\hline A R T I C L E I N F O & A B S T R A C T \\
\hline $\begin{array}{l}\text { Review Article } \\
\text { Received : 14/08/2018 } \\
\text { Accepted : 01/02/2019 } \\
\text { Keywords: } \\
\text { Pulse } \\
\text { Drought stress } \\
\text { Morphological } \\
\text { Yield } \\
\text { Physiological }\end{array}$ & $\begin{array}{l}\text { Pulses in Pakistan is used in combination with cereals to balance the diet. Its area and production } \\
\text { is decreasing for last many years. In the barren and partly arid regions, water shortage is the major } \\
\text { component that restricts yield. Using of drought resistance plant is one of the best ways for good } \\
\text { cultivation under drought condition. As the pulses have great nutritional and economical values } \\
\text { and drought stress affect their morphological features. The legume yield is mostly cultured in rain } \\
\text { fed region of the Punjab where they bear a slighter quantity of water situation resulting in low } \\
\text { yield of bean. To overcome these problems it is necessary to get knowledge about the performance } \\
\text { of different lines of different pulses crops under water stress conditions. That's why in this paper } \\
\text { the information about the previous literature has been discussed. }\end{array}$ \\
\hline
\end{tabular}

(c) $)$ () \& 9 This work is licensed under Creative Commons Attribution 4.0 International License

\section{Introduction}

We all know that pulses play a vital role in our lives. Pulses are the cheapest source of dietary proteins. The pulses are also known for increasing productivity of soil through fixation of nitrogen from atmosphere, addition of biomass to soil and secretion of growth promoting substances. Pulses are well suited in rainfed conditions and require less farm resources; hence farmers prefer to grow them from economic point of view throughout the country.

Lentil is an annual crop belonging to Leguminoseae (Fabaceae) family. Lentil yield include elevated protein essence, and identified the third-greater intensity of protein of any nut, subsequent to soybean and drugs ranges of grain protein substance varies from $22 \%$ to $34.6 \%$ (Callaway et al., 2009). The consequent major developed pulse yield of Rabi season in Pakistan after chick-pea (Cicer arietinum $L$.) is lentil both in excellence and abundance (Ayub et al., 2001). In current time bean construction in Pakistan has reduced due to its poor competenceability with Major Rabi crop considerably. Most food crops rely on 3 necessary micronutrients originate in the soil for optimal plant development; nitrogen, phosphorus, and potassium. The legumes are significant cause of crucial trace mineral, glyceride and amino acids (Zia-Ul-Haq et al., 2011). Water tension is the main trouble in cultivation and the capability to survive such pressure is efficiently important. Using of drought resistance plant is one of the best ways for good cultivation under drought condition. As the lentil (Lens culnaris Medik) has great nutritional and economical values and drought stress affect the morphological features of lentils (Lens culnaris Medik). The legume yield is mostly cultured in rain fed region of the Punjab where they bear a slighter quantity of water situation resulting in low yield of bean. The present reading is split to evaluate advance accession of legume underwater strain circumstances to recognize the budding dearth contrasting lines.

Drought is a frequent and insensitive restriction to harvest yield in many regions of the earth where lentil were full-fledged (Mc William, 1986). Lack of stress develops into the major constraint feature on plant harvest at worldwide degree (Yordanov et al., 2000). Owing to the excessive water scarcity, contract cells and mechanical damage happen on sheath. The entire defects scratch the performance of ions, transporters and sheath based enzymes (Mahajan and Tuteja, 2005). Among all constituent limitation yield capability and famine remnants are affecting the world protection and sustainability in farming assembly. A fall in water potential induces a collection of morphological or physiological, metabolic and responses excluding decline in the vegetative expansion. Along with the ecological stresses, famine is one of the most unfavourable components for plant 
expansion and efficiency (Reddy et al., 2004; Makbul et al., 2011). Drought stress causes a series of anatomical, chemical element and structural reaction of harvest, to conclude results in less yield of mung bean (Malik et al., 2006).

Water stress is very significant constraint character at the primary stage of plant development and institution. Drought effects together enlargement and extension growth (Jaleel et al., 2009). Another water shortage effect is the lessening of vegetative growth.

When soil water is regularly exhausted, an amount of plant purpose is reduced but leaf expansion is one of the first to condense. In barren mud, growth of root is greatly less depressed than expansion of shoot and there is characteristically a reduced in the desiccated mass percentage of shoot and root in response to drought stress (Hsiao, 2000). Alternate to important drought stress can decrease plant genotype, amount of shell and grains, development period, yield display; grain acquiesces and seed mass in plants (Ramirez- Vallejo and Kelly, 1998). Water stress throughout vegetative has the highest effect on height of plant and biological yield (GhassemiGolezani and Mardfar, 2008). Throughout the generative increase water scarcity has a consequence on crop effectiveness (Costa- Franca et al., 2000). Water is one of the most ecological factors for adaptable plant development and expansion (Toker and Cagirgan, 1998).

Low moisture stress slow down the plant growth and they start to build up active osmolyte (compounds that are characteristics as non- toxic, highly soluble and having low mol. wt) in their cells and this process is called osmotic adjustment. In all parts of the plants osmotic regulation occurs including stem, leaf root and fruit (Unyayar et al., 2004). Ionic variation is one of the main significant strategies that plants approved to tolerate under water deficiency stress condition (Otieno et al., 2005; Afkari et al., 2009). These osmolytes help the plants to show protective reaction against drought injure (Reddy et al., 2004; Shao et al., 2005) as these helps the plants to retain water assimilation and cell turgid potential under stress condition.

\section{Objective}

Objective of this review is to study all those parameters and factors which perform well under water stress and which are affected seriously under this stress and also we can find who different crops reacted toward this stress. Furthermore by literature we can improve our genotypes as well by using different strategies which are well suited to our environment and will perform well in water stress conditions.

\section{Morphological and Yield Related Traits}

Giovanardi and Ceccon (1987) investigated that in Soybean water stress during flowering reduce leaf area growth but the growth was increased when the stress was removed. Water stress during flowering had the maximum effect on total dry material and seed yield dropping it to about $45 \%$ of the well irrigated pots as against 58 and 71 to $80 \%$ for water stress during the vegetative and maturity phases correspondingly.
Ashraf and Karim (1991) deliberate the consequence of water anxiety on ten cultivars of black gram in pot experimentation. The Qandhari squash, from a deficiency flat area twisted extensively larger biomass, elevated plant water contents, further epi-cuticular wax moreover noticeable facility intended for osmotic modification contrast with further cultivars. Shoot protein meditation of for the most part of the cultivars improved below dampness pressure, but to facilitate of Qandhari mash wait impervious.

Marouelli et al. (1991) examined peas to facilitate elevated soil water anxiety abridged the enlargement era plus shoot dry heaviness. They further renowned to 1000 seed substance amplified by means of rising anxiety as well as was uniformly pretentious by top soil water anxiety through vegetative plus reproductive development stage.

Ferreira et al. (1992) accomplished to facilitate in groundnut with $100 \%$ irrigation flowering pointed after 5 weeks, excluding cruel water stress condensed this to 2 weeks. Pod acquiesce was maximum for everlasting irrigation below each water association. Growing water stress reduced leaf area, quantity of leaves as well as flowers, shelling entitlement moreover reproductive chapter.

Golakiya, (1993) examined that in groundnut cultivar J-11 water stress at flowering, pegging, pod growth and pod maturation stages decreased pod yield by 26.6, 44.7, 56.3 and $6.0 \%$ correspondingly. Equivalent reduction in GAUG-10 water 12.6, 15.0, 38.3, and 5.8\% in that order.

Ney et al. (1994) conducted that in peas, drought strain affected yield of indistinct variety, but the effect on yield component, seed number and entity seed weight at harvesting stage were in some cases incompatible.

Costa et al., (1997) determined in potato, that premature time drought stress considerably minimized the water use efficiency, chief to deeply reduced development and biomass assembly. Infect, even though method of plant water transactions.

Abdollahian- Noghabi and Froud- Williams (1998) analyzed that drought stress decrease the growth of shoot and root but there was less variation in root growth and they examined large reduction in the leaf area and a small reduction in the root growth of sugar beet when drought stress was applied.

Pace et al. (1999) analyzed the drought effect on cotton (Gossypium hirsutum L.). In their research they observed root and shoot growth of elongated- small varieties of cotton. They were sampled plants after a 13-d and once more in recovery stage. At the end of famine and regeneration, they were examined that no of nodes, plant height, leaf area, and the dry weights of the stems and leaves were reduced in stress condition. They calculated that growth of root was not reduced in the drought treated plants, compared with the non stress condition.

Kamara et al. (2003) observed that famine stress deeply decline the crop particle, which was reliant on the level of leaf falling owing to water strain throughout early reproductive development of crops.

Mohammadiani et al. (2005) conducted an experiment on 9 honey beet fertilizers to investigate the reaction of early season famine stress on growth characters. The analysis tested was accurate famine stress, moderate famine stress and non stress condition. In their experiment 
they recognize the petal area index, leaf desiccated influence shoot dry density and dry weight of root reduced under deficiency strain compared to non strain circumstances. They were observed that the decline was further evident as the velocity of strain improved. Petal area index was extra conceited by water strain than leaf density correspondingly, and losses of whole dry weights of leaf were $16.2 \%$ and $54.2 \%$ in gentle and harsh stresses, in that order. The majority of the cultivars with a low shoot to root ratio and elevated dry weight of root before execution of strain also had a lesser dry weight of root under strain than non strain and formed elevated white honey harvest.

Manikavelu et al. (2006) conducted an experiment to learning the consequence of drought on rice. They reported that drought stress during vegetative stage greatly reduce the plant expansion and improvement.

Zeid and Shedeed (2006) work on alfalfa (Medicago sativa) they observed the germination potential, hypocotyls length, shoot and root new and dry weights were condensed by water deficit stress, while the root length was improved.

Khan et al. (2006) an experiment was conducted under glasshouse to explore the consequence of different water constant at diverse expansion period of four chosen chili lines viz, C- 0277, C-0272, and C-0271, Six water analysis viz., watering one time every day (W1), watering two times every day (W2), watering at 4 days distance (W3), watering at 8 days period (W4), watering at 16 time gap (W5), and no watering (W0) were experienced at three development stages viz., flowering stage (S2), Fruiting stage (S3) and vegetable stages (S1). The results exposed that all the examined parameters viz., fruit length, canopy temperature, plant height, individual fruit weight, fruit diameter, root length, root dry weight, leaf dry weight, root volume, no of fruits per plant, stem dry weight, leaf area per plant, no of leaves per plant, fruit dry weight, per plant and yield per plant, varies considerably among the extension beneath dissimilar water regimes at distinct period of expansion. Two lines, C-0271 and 0277 were establish as water pressure moderate and vulnerable, in that order.

Mohammadkhani and Heidari (2007) conceded out an experiment on two zea mays L. cultivar to investigate the effect of low water potential on plant soluble protein content. The treatment applied were water potential nil of the control. The observed that by the declining entire soluble protein, water potentials substance first greater and then decline in the leaves and roots of both treatments in drought situation. The reduction in shoot and root fresh weight in cv.201 was improved than in cv. 301. They recommended that there was negative correlation between drought tolerance and protein alteration in a cowpea breeding programmed.

Bilgin et al. (2008) examined the effects of drought on shoot period of corn. They were examined some shoot and root characters. In this experiment they were applied four water treatment. The principal standards for root desiccated substance, sheet water failure and spurt bright mass were achieved in diverse treatment. In general, water management reduces all the traits apart from the leaf fresh weight and quantity of leaves per plant.75\% available water action caused in raising the shoot and root length, fresh weight for root and shoot, number of leaves per plant, dry substance of root and shoot, and leaf fresh weight. The lower values for all the traits were achieved by $25 \%$ obtainable water analysis.

Branabas et al. (2008) examined deficiency stress affects crop expansion and yield for the duration of all developmental stage. The effect of drought on harvest is greatly composite and associate procedure as various as reproducing organs, enrichment and seed growth stress

Zaefyzadeh et al. (2009) observed plants under deficiency stress and found that since a consequence of ecological stresses, Sodium oxidize dismutase action of cells enlarge as a tolerance method. Important stage of grass action is a display of resistance to the stress feature.

Ahmad et al. (2009) found that sunflower (Helianthus annuus L.) is susceptible to water shortage at the germination phase. In sunflower, low water accessibility in the soil has a negative impact on yield.

Roy et al. (2009) carried out an experiment with 39 bold grained rice genotypes to examine the genetic changeability of the characters conferring deficiency struggle. This field experiment was conducted to approximate the inherited changeability of eight morphological parameters; root weight $(\mathrm{g})$, number of primary roots, number of tillers, shoot mass $(\mathrm{g})$, root length (cm), root: shoot ratio by mass as well as root: shoot ratio by length. The data for the morphological traits were recorded after 60 days of transplanting.

Pervez et al. (2009) examined an experiment to learn the effect of drought on tomato. In this research drought behavior was applied at different growth stages of tomatoes. Four treatments were i.e. early stress, center anxiety, delayed pressure, while control no stress was forced. In this conduct experiment they observed that a variety of expansion attributes, shoot extent, and shoot fresh mass, root fresh heaviness as well as plant height were decline due to obligation of the stress treatment. While in control expansion attributes were improved.

Naroui Rad et al. (2010) calculated the effect of water strain on lentil genotypes irrigation was applied in both blossoming and harvesting period. The experiment was conducted in common and stress circumstance with randomized complete block design. There was positive correlation in \% point with yield in famine and standard form like, drought index stress, geometric mean productivity (GMP) and Tolerance index (STI).

Boutraa et al. (2010), accomplished an experiment to examine water pressure on wheat varieties. They were used placid $(50 \%)$ furthermore harsh $(30 \%)$ irrigate scarcity regimes by way of a control of $80 \%$ top soil field capability. The consequence of irrigate stress on expansion characters including; plant height, dry weight of roots shoot leaf area, and entire plant. In the end of result they observed that the mild water shortage affected Sindy-2 and Hab Ahmar, while Al-gaimi was less affected with neither decrease in root dry weight nor change in dry weight. Under harsh pressure, development was diminishing.

Eman et al. (2010), conducted research to conclude reaction of two widespread bean (Phaseolus vulgaris L.) varieties through diverse development behaviour to irrigate stress situation. Four stress levels were used. The consequences reveal to facilitate plant elevation, leaves number, figure of pods for every plant, number of pods, total kernel weight, 1000 kernel weight as well as whole 
dry mass of both cultivars responds drastically to irrigate strain situation. Water pressure also reduced shoot elevation and concentrated leaf vicinity. Additionally, it condensed pod dried up mass in equally varieties along with water stress levels, every one plant pods of mutually varieties were aborted.

Ranawke et al. (2011), examined experimentation to reading the consequence of water lacking anxiety on mungbean at diverse expansion phases i.e. 3WAP, 6WAP and 8WAP. They analysed that drought influence all the growth characters expect tap root extent at early phase, Number of flower buds and pods/plant significantly condensed at reproductive period and weight/plant at adult phase.

Khan et al. (2011), investigated the physiological traits under drought pressure. The consequence indicated that dearth stress considerably decrease dehydrated influence of root, flowers of plant, fruits rest percent, pod give way, days to flowering and maturity.

Dabbagh and Nasab (2011) observed the special property of water latent on germination and plantlet expansion of two varieties of lentil. The two varieties were directed to famine stress. While drought strain raises the sprouting proportion, propagating speed, usual seedling fraction, dries mass as well as root/shoot length of seedling. The consequences displayed that deficiency strain caused noteworthy reduction in sprouting fraction of Ziba and ILL4400 correspondingly, Root shoot ratio of seedling for $\mathrm{V} 1$ and V2 decreased.

Yaqoob et al. (2012), determined two chickpea varieties. They experienced them beneath two humidity level, fine irrigation and damp strain. The results demonstrate the effect of a variety of moisture levels was only considerable for shoot fresh weight. Considerably elevated shoot fresh mass and shoot damp was analyzed in fine irrigation management as well as lesser shoot fresh mass and less shoot humidity was calculated in moisture stress action.

Khakwani et al. (2012) calculated the reaction of wheat under (100\% field capability) and dearth pressure (35\% field ability). Investigation of variation showing substantial consequence of water stress on stomatal conductance, stomatal density, stomatal dimension, relative water content, leaf fresh weight, leaf area, leaf dry mass, definite leaf area (SLA), and biological yield per plant. Even though all characters behaved independently but considerably for mentioned biological and crop traits, like Hashim-8, Zam-04 and barrage revealed slightest decrease when grown under dearth state and same rain fed varieties retained low level of stomata height and stomatal width under scarcity stress condition and higher level of stomatal conductance.

Aslani et al. (2012), observed the grain and plant Improvement Institute, Karaj (Iran) in growing season to reading the consequence of two watering regions common washing and no watering in development period on seed crop of eight wheat varieties. Although as a result of investigation, it is obvious that there is a substantial variation between the hard varieties in seed harvest and resigns method. Under dissimilar irrigation regimes there is a huge distinction in seed yield decline among genotypes. In both conditions DN-11 Genotype formed the maximum seed yield. On the basis of as well as regression analysis, mainly considerable harvest equipment was natural crops, crop indicator, and 1000 seed yield.

Talukda (2013) investigated an experiment on bean (Lens culinaris Medik.) and Indian pea (Lathyrus sativus L.). Drought stress was applied for 20 days. The results revealed that the water pressure encourage alteration in expansion characters such as number of primary branches and number of leaves per plant, plant height, dry mass of roots and shoot. All these development traits reduced in both crops.

Atif et al. (2013) studied the morphological traits for two drought conflict varieties of marigold (Tagetes erecta L.) (Super Giant). Although four deficiency levels like, grassland capability were retained during the research. Structural parameters involved crop quality, plant tallness, number of petals/plants, leaf region, shoot dimension, root range, root and fresh weight of shoot and root-shoot ratio for bright and arid mass. The conclusion exposed that superiority of whole plants variations reduce with the progressive of famine pressure.

Imani et al. (2013), examined the association between a number of physiological parameters with famine tolerance in legumes varieties, 10 modern varieties of lentil, under non -stress and lethal drought stress situation. For the removal of enzymes leaf tissues at regenerative period $(10,20$ and 30 day after reproductive stage) were used. They analysed the effect of water pressure and famine stress circumstances for the enzyme action of superoxide dismutase and catalase - ascorbate- peroxides (CAT) was no significant, stages (10, 20 and 30 day after reproductive stage). The results indicated that the enzymes activity rate improved in the biological period at famine situation.

Amini et al. (2013), determined the effect of diverse dearth pressure regimen and fodder cultivars on expansion characters of legumes (Lens culnaris Medik.). The drought stress cultivars departure from class A pan, correspondingly) were applied. The results revealed that among famine pressure cultivars, the maximum height of plant, grains per pod, number of stem per plant, pods per plant, seed per plant were improved in grouping with straw mulch.

Uddin et al. (2013) examined that Mungbean is most susceptible in that compliments neither tolerate scarceness nor the excess wetness. Hence, the present investigation was performed to estimate water pressure significance on the morpho-biological varieties of mungbean. The experiment explained seven varieties of watering in a variety of expansion phase. Consequences showed that damp pressure delayed the mungbean expansion considerably and condensed the expansion velocity. Damp shortage resulted higher display and shell exclusion (53\%) which improved early maturation of mungbean. The main dangerous period is flowering to maturity where water shortage reduced shell dried out material. Sustain sufficient mud dampness throughout the period of flowering to pod maturation confident heavy pod and make sure elevated seed of mungbean.

Zare et al. (2013), examined that water shortage is the main factor that restrict nature of crop arid and semi arid regions. Grassland experiments were conceded out in a Randomized Complete Block Design with three replications, to observe the force of famine stress on 
mungbean (Vigna radiate L.) genotypes. All the experiments were in same circumstance and the reachable variety along with was discontinue the watering in one of the research at flowering phase till whole stage of maturity (S1) and was discontinue the irrigation at grain filling phase in (S2). As a consequence of reciprocal investigation of variation crosswise surroundings revealed that the entire calculated parameters were disposed by famine pressure situation. Under drought stress situation seed yield was affected and it was condensed as compared to non strain form that decrease pods per plant, no of leaves, and 1000 grain mass in first situation and shell duration, pod dry mass, dry weight of root and number pods per plant in S2 condition. Pakistan breeders had the minimum seed yield in strain and non-stress situation as compare to India.

Hadi et al. (2014), carried out a research to calculate and evaluate the deficiency tolerance in sprout of significant yield. In this experiment polythene glycol helpful for stimulation of dearth stress and contrasted their consequence on seedling growth, seed development and plant biomass and water substance. Different treatments of PEG were added to growth medium. They observed that grain development decreased considerably with growing deliberation of PEG, transitional growth was recognized. Likewise shoot: root length and genotype decline with rising deliberation of polythene glycol. The development traits greatly decreased due to PEG. In this research they analysed that canola had elevated famine shoot and root length, biomass, tolerance in respect of grain development, and tomato was moderate and cauliflower was found very susceptible to famine stress.

Tsago et al. (2014), examined an experiment to determine the effects of drought on Sorghum bicolor. The experiment was conceded on sixteen sorghum types moreover data were evidence at five diverse polythene glycol 6000 rank on coleoptiles extent, extent of root, fresh shoot mass, fresh root mass, root quantity. They convenient the vital decrease in the development traits between them. They resolute that growth traits like, root extent, fresh root as well as shoot mass reduced owing to drought pressure.

Jamian et al. (2014), executed experiment on medicinal plants. This revise was accepted in sort to inspect the possessions of deficiency pressure at serious phase of plant days (seed sprouting). The cause of deficiency anxiety at the stage of $0,-2$ and -4 bars tempt by PEG on sprouting moreover plantlet escalation of three essential medicinal plants. In this trial germination speed plus percentage, root extent, shoot extent, root to shoot extent and root shoot part, root fresh mass as well as shoot fresh mass were calculated. The consequences pointed toward to facilitate drought diminish germination speed in medicinal plants.

Nasab et al. (2014), determined the significance of various levels of auxin and superabsorbent hormone on yield and yield mechanism of mung bean, in RCBD with four replication at Islamic University. They used three main plots of superabsorbent $(0,60,120 \mathrm{~kg} / \mathrm{ha})$ and three sub plots of auxin hormone $(0,10,15 \mathrm{ppm})$. They determined that easy and interface effects of superabsorbent and auxin on length of pod, plant height, grain and organic yield were substantial. But the harvest index was only inclined by the easy result of superabsorbent. Mean comparisons displayed that the raise of superabsorbent application up to $120 \mathrm{~kg} / \mathrm{ha}$ lead to the major improvement of exceeding traits by $14.91,13.26$, 11.17 and $18.46 \%$, correspondingly in assessment to lacking significance of superabsorbent organization and use of $15 \mathrm{ppm}$ auxin caused the great increase of those characters by $14.88,13.26,18.67$ and $17.71 \%$, correspondingly in contrast to without application of auxin treatment. The result displayed that the excellent treatment for optimum yield within the examined state was the one with consequence of $120 \mathrm{~kg} / \mathrm{ha}$ superabsorbent and $15 \mathrm{ppm}$ auxin.

Babayeva et al. (2014), recognized the deficiency forbearance of legumes lines gathered from area throughout two forms of grass research condition: watering and well-fed. Various harvest mechanism of these accretions were examined and evaluate by indicate of arithmetic study. Inspection of variation showed substantial distinction among the varieties and contained investigational situations. Number of grain and shell per plant had important relation along with grain harvest per plant on the basis of regression analysis. Bunch analysis found on dearth tolerance indicator crowd succession into different subclass with various figures of succession in each group. As well as cluster were distinguishing by elevated drought tolerance index principles and elevated yield were observed in both circumstances. Combined assembly of variety recognized precious germplasm parameters under pressure and May consequently harsh as cause of precious factors in lentil reproduction for deficiency approval.

Sepanlo et al. (2014), conducted the morphological and physiological response of soybean genotypes to water shortage in a field research with three diverse soybean genotypes at three dissimilar irrigation regimes was conceded out. Plants were developed either under optimum condition, drought stress implemented before the flowering period and pod-filling stage (post-anthesis). In both blossoming and pod filling growing stages, seed yield and calculated morphological traits, except for number of seeds per plant and seed protein content, reduced from common irrigation system to water shortage strain. In all genotypes leaf effective water matter was significantly decreased due to water scarcity in both budding stages as well as in strained environment had progressive fall in chemical osmolytes and chlorophyll material. They accomplished that drought stress condense the growth and metabolic action of soybean genotypes. These parameters showed substantial changeability under drought at different growth stages in soybean.

Hussain et al. (2015), examined a field research with three replications during Rabi 2012-2013 with two positions each contain 13 haricot genotypes in stress and non stress condition. The purpose of the examined experiment was to analyse the reaction of chickpea genotypes in drought stress and to observe the suitable genotypes carry out better in lack of water and watering condition. In stress situation three genotypes exhibited best famine tolerance efficiency outstanding harvest index least drought susceptibility index and least decline in number of seed crop.

Rahimi et al. (2016), examined the consequence of scarcity strain on physiological traits of lentil by using hereditary lines beside with their parents with three replications in RCBD plan. In both standard and stress 
condition analysis of variation showed vital distinction between lines in conditions of all measured traits. Dearth pressure condition reduced number of pod per plant, seed yield, and pod mass per plant correspondingly. Association coefficient of number of pod per plant, grain yield, and biological index with grain succumb was productive and considerable.

\section{Conclusion}

Different crops respond differently toward different stresses. Pulse is an important crop in all the aspects. Drought stress is a serious issue in pulses and very less work has been done on this in Pakistan. We found that what are the consequences of stress on these crops and hoe they behave towards this. What strategies we can use to develop the resistant genotypes to obtain a good yield. This information will be used in future for further improvement of our material.

\section{References}

Abdollahian NM, Williams FRJ. 1998. Effect of moisture stress and re watering on growth and dry matter partitioning in three cultivars of sugar beet. Asp. Appl. Biol., 52: 71-78.

Afkari BA, Qasimov N, Yarnia M. 2009. Effects of drought stress and potassium on some of the physiological and morphological traits of sunflower (Helianthus annus L.) cultivars. J. Food Agric. Environ., 7: 448-451.

Amini R, Milani MA, Mohammadinasab AD. 2013. Effect of different irrigation treatments and mulch on water use efficiency of lentil (Lens culinaris Medik.). Int. J. Bio. Sci., 4: 44-49.

Ashraf M, Karim F. 1991. Screening of some cultivars/lines of black gram (Vigna mungo L.) Hepper) for resistance to water stress. Trop. Agric. J., 68: 57-62.

Aslani F, Mehrvar MR, Juraimi AS. 2012. Evaluation of some morphological traits associated with wheat yield under terminal drought stress. African J. Agric. Res., 7: 4104-4109.

Atif R, Younis A, Taj AR, Karim A, Tariq U, Munir S, Riaz S. 2013. Effect of drought stress on growth and flowering of marigold (Tagetes ercta L.). Pak. J. Bot., 45: 123-131.

Ayub K, Rahim M, Khan A. 2001. Performance of exotic lentil varieties under rainfed conditions in Mingora (NWFP) Pakistan. J. Bio. Sci., 1: 343-344.

Babayeva S, Akparov Z, Damani A, Izzatullayeva V, Aslanova G, Abbasov M. 2014. Genetic diversity for drought tolerance in lentils from Central Asia and the Caucasus: CACLentil. Albanian j. agric. sci., 13: 1-8.

Baranbas B, Jagar K, Feher A. 2008. The effect of drought and heat stress on reproductive processes in cereals. Plant Cell Environ., 31: 11-38.

Bilgin O, Aser I, Korkut KZ, Balkan A, Saglam N. 2008. The impacts on seedling root growth of water and salinity stress in maize (Zea mays indentata Sturt.). Bulg. J. Agric. Sci., 14: 313-320.

Bourtraa T, Akhkha A, Al-Shoaibi AA, Alhejeli AM. 2010. Effect of water stress on growth and water use efficiency (WUE) of some wheat cultivars (Triticum durum) grown in Saudi Arabia. J. Turk. Sci., 3: 39-48.

Callaway JC. 2009. Hempseed as a nutritional resource: An overview: Euphytica, 140: 65-72.

Costa LD, Vedove GD, Gianquinto G, Giovanardi R, Peressotti A. 1997. Yield, water use efficiency and nitrogen uptake in potato influence of drought stress. Potato Res., 40: 19-34.

Costa-Franca MG. Thi AT, Pimenta C, Pereyra RO, Zuily-Fodil Y, Laffary D. 2000. Differences in growth and water relations among Phaseolus vulgaris cultivars in response to induced drought stress. Environ. Exp. Bot., 43: 227-237.
Dabbagh A, Nasab M. 2011. Effects of water potential on germination and seedling growth of two varieties of lentil (Lens culinaris Medik.). Int. Agricrop. Sci., 3: 61-64.

Eman Y, Shekoofa A, Salehi F, Jalali AH. 2010. Water stress effects on two common bean cultivars with contrasting growth habits. Am-Euras. J. Agric. Environ. Sci., 9: 495-499.

Ferreira LGR, Santos IFD, Tavora FJF, Dasilva JV. 1992. Effect of water deficit on groundnut (Arachis Hypogaea L.) cultivar. Physiological reactions and yields. Repostas fisialogicas a produce. Oleagineux (Paris), 47: 523-530.

Ghassemi-Golezani K, Mardfar RA. 2008. Effect of limited irrigation on growth and yield of common bean. J. Plant. Sci., 3: $230-235$.

Giovanardi R. Ceccon P. 1987. Phenology and vegetative behavior of soyabean as affected by water availability in two different soils. Commune di Cesena; Soyabean Absts., 12: 389-396.

Golakiya BA. 1993. Drought response of groundnuts. VII Identification of the crucial growth stages most susceptible to water stress. Adv. P. Sci., 6: 20-27.

Hadi F, Ali MSS, Shafiq M, Ullah R, Jan AU. 2014. Comparative effect of polyethylene glycol and mannitol induced drought on growth (in vitro) of canola (Brassica napus), cauliflower (Brassica oleracea) and tomato (Lycopersicon esculentum) seedlings. Int. J. Bio. Sci., 48: 34-41.

Hsiao TC. 2000. Leaf and root growth in relation to water stress. Horti. Sci., 35: 1051-1058.

Hussain N, Aslam M, Ghaffar A, Irshad M, Naeem-ud-Din. 2015. Chickpea genotypes evaluation for morpho-yield traits under water stress conditions. J. animal and plant sci., 25: 206-211.

Imani A, Shahbazi H, Saifolahi R. 2013. Antioxidant response of lentil genotypes (Lens culinaris Medik.) to drought stress in different reproductive growth stages. J. Basic. Appl. Sci., Res., 3: 738-743.

Jaleel CA, Manivannan P, Wahid A, Fraooq M, Al-juburi HJ, Somasundaram R, Panneerselvam R. 2009. Drought stress in plants on morphological characteristics and pigments composition. Int. J. Agric. Biol., 11: 100-105.

Jamian SS, Mehrani S, Asilan KS, Tabrizi AT, Goharian A. 2014. Responses of seedling growth and germination parameters in three medicinal plants under drought stress. Int. J. Agric. Crop Sci., 7: 191-195.

Kamara AY, Menkir A, Badu-Apraku B, Ibikunle O. 2003. The influence of drought stress on growth, yield and Yield components of selected maize genotypes. J. Agric. Sci., 141: 43-50.

Khakwani AA, Dennett MD, Munir M, Baloch MS. 2012. Wheat yield response to physiological limitation under water stress condition. J. animal and plant sci., 22: 773-780.

Khan I, Jan AU, Gul F, Ali K, Ahmed S, Ahmad N. 2011. Weeds as a major constraint in wheat production in district Peshawar. Pak. J. Weed Sci. Res., 17: 381-386.

Khan MAI, Farooque AM, Hoque MA, Rahim MA, M.A. 2006. Effect of irrigation levels at different growth stages on growth parameters and yield of four selected chilli accessions. Bang. J. Agric. Res., 34: 143-155.

Mahajan S, Tuteja N. 2005. Cold, salinity and drought stresses. Arch. Biochem. Biophys., 444: 139-158.

Makbul S, Saruhan-guler N, Durmus N, Guven S. 2011. Changes in anatomical and physiological parameters of soybean under drought long term drought. Turk. J. Bot., 35: 369-377.

Malik A, Hassan F, Waheed A, Qadir G, Asghar R. 2006. Interactive effects of irrigation and phosphorus on green gram (Vigna radiata L.). Pak. J. Bot., 38:1119-1126.

Manikavelu A, Nadarajan N, Ganesh SK, Ganamalar RP, Babu RC. 2006. Drought tolerance in rice: morphological and molecular genetic consideration. Plant Growth Regul., 50: 121-138.

Marouelli WA, Giordano LDEB, Das CA, Oliverira, Carrijo OA. 1991. Development, yield and quality of peas under different soil water tension. Pesquisa Agropecuaria Brasileria 26: 1041-1047. 
Mc-William JR. 1986. The national and international importance of drought and salinity effects on agricultural production. Ann. J. Plant. Physiol., 13: 1-13.

Mohammadiani R, Moghaddam M, Rahimian H, Sadeghian SY. 2005. Effect of early season drought stress on growth characteristics of sugar beetbgenotypes. Turk. J. Agric., 29: 357-368.

Mohammadkhani N, Heidari R. 2007. Effect of drought stress on soluble protein in two maize varieties. Turk. J. Biol., 32: 2330.

Naroui R, Ghasemi MRA, Arjmandinejad A. 2010. Study of limit irrigation on yield of Lentil (Lens culinaris) genotypes of national plant gene bank of Iran by drought resistance indices. J. Agric. \& Environ. Sci., 7 (2): 238-241.

Nasa SVM, Moosavi SG, Nejad TS. 2014. Effect of different levels of superabsorbent and foliar application of auxin hormone on yield and morphological traits of mungbean (Vigna radiata L.) Int. J. Biosci., 4: 238-240.

Ney B, Duthion C, Turc O. 1994. Phenological response of pea to water stress during reproductive development. Crop. Sci., 34: 141-146.

Otieno DO, Schmidt MWT, Adiku S, Tenhunen J. 2005. Physiological and morphological response to water stress in two Acacia species from contrasting habitats. Tree Physiol., 25: 361-371.

Pace PF, Harry T, Sherif C, El-Halawany HM, Cothren JT, Senseman SA. 1999. Drought-induced changes in shoot and root growth of young cotton plants. J. Cot. Sci., 3: 183-187.

Pervez MA, Ayub CM, Khan HA, Shahid MA, and Ashraf I. 2009. Effect of drought stress on growth, yield and seed quality of tomato (Lycopersicon esculentum L.). Pak. J. Agric. Sci. 3: 24-35.

Rahimi MH, Houshmand S, Khodambashi M, Shiran B, Mohammady S. 2016. Effect of drought stress on agromorphological traits of lentil (Lens culinaris Medik.) recombinant inbred lines. Bangladesh. J. Agri. Res., 41: $207-$ 219.

Ranawake AL, Amarasingha UGS, Rodrigo WDRJ, Rodrigo UTD, Dahanayaka N. 2011. Effect of water stress on growth and yield of mungbean (Vigna radiate L.). Trop. Agric. Res. Exten., 14: 76-79.

Reddy AR, Ramachandra Rk, Chaitanya V, Vivekanandan M. 2004. Drought induced responses of photosynthesis and antioxidant metabolism in higher plants. J. Plant Physiol., 161: 1189-1202.

Roy R, PB Mazumder and GD Sharma. 2009. Proline, catalase and root traits as indices of drought resistance in bold grained rice (Oryza sativa) genotypes. Afr. J. Biotechnol., 8: 65216528.
Sepanlo N, Talebi R, Rokhzadi A, Mohammadi H. 2014. Morphological and physiological behavior in soybean (Glycine $\max \mathrm{L}$.) genotypes to drought stress implemented at pre- and post-anthesis stages. Int. J. Agric. Biol., 58: 109-113.

Shao HB, ZS Liang MA Shao. 2005. Some antioxidant enzymes under soil water deficits among 10 wheat genotypes at maturation responses of durum wheat Iandraces (Triticum aestivum) stage. Colloids Surf. B. Biointerf., 45: 7-13.

Talukda D. 2013. Comparative morpho-physiological and biochemical responses of lentil and grass pea genotypes under water stress. J. Nat. Sci. Bio. Med., 4: 396-402.

Toker C, Cagirgan MI. 1998. Assesmest of responses to drought stress of chickpea (Cicer arietinum L.) lines under rain field conditions. Turk. J. Agric. For., 22: 615-621.

Tsago Y, Andargie M, Takele A. 2014. In vitro screening for drought tolerance in different sorghum (Sorghum bicolor $\mathrm{L}$. Moench) varieties. J. Physiol. Biochem., 9: 72-83.

Tsago Y, Andargie M, Takele A. 2014. In vitro screening for drought tolerance in different sorghum (Sorghum bicolor $\mathrm{L}$. Moench) varieties. J. Physiol. Biochem., 9: 72-83.

Uddin S, Parvin S, Awal MA. 2013. Morpho-physiological aspects of mungbean (Vigna radiata $\mathrm{L}$.) in response to water stress. Int. J. Agric. Sci. Res. 3: 137-148.

Unyayar S, Keles Y, Unal E. 2004. Proline and ABA levels in two sunflower genotype subjected to water stress. Blug. J. Plant Physiol., 30: 34-37.

Yaqoob M, Hoilngton PA, Gorham J. 2012. Shoot, roots and flowering times studies in chickpea (Cicer arietinum L.) under two moisture regimes. Em. J. Food Agric., 24: 73-78.

Yordanov I, Velikova V, Tsonev T. 2000. Plant responses to drought, acclimation and stress tolerance. Photosynthetica, 38: 171-186.

Zaefyzadeh M, Quliyev RA, Babayeva SM, Abbasov MA. 2009. The effect of the interaction between genotype and drought stress on the superoxide dismutase and chlorophyll content in durum wheat landraces. Turk. J. Biol., 33: 1-17.

Zai-ul-Haq M, Ahmed S, Shad MA, Iqbal S, Qayum M, Ahmed A, Luthria DI, Amarowicz R. 2011. Composition studies of lentil (Lens culinaris) cultivars commonly grown in Pakistan. Pak. J. Bot., 43: 1563-1567.

Zare M, Dehghani B, Alizadeh O, Azarpanah A. 2013. The evaluation of various agronomic traits of mungbean (Vigna radiate L.) genotypes under drought stress and non-stress conditions. Int. J. Farming and Allied Sci., 2: 764-770.

Zeid IM, Shedeed ZA. 2006. Response of alfalfa to putrescine treatment under drought stress. Biol. Plant., 50: 635-640. 